\title{
Pengaruh Profesionalisme Guru Terhadap Peningkatan Prestasi Belajar Siswa Kelas X Di Madrasah Aliyah Muhammadiyah 02 Pondok Modern Paciran Lamongan
}

\author{
Himmatul Husniyah \\ Sekolah Tinggi IlmuTarbiyah Muhammadiyah Paciran Lamongan, Indonesia \\ E-mail: himmatulhusniyah11@gmail.com
}

\begin{abstract}
Abstack, This study aims to identify teacher professionalism towards the improvement of student achievement in class $X$ at Madrasah Aliyah Muhammadiyah 02 Pondok Modern PaciranLamongan. The hypothesis proposed is "there is an effect of teacher professionalism on the improvement of student achievement in class X students at Madrasah Aliyah Muhammadiyah 02 Pondok Modern PaciranLamongan". To test the correctness of the instrument hypothesis in the form of a questionnaire distributed to 10 professional teachers and 30 class $X$ students, the proposed analysis model is Karl Pearson Product Moment Correlation at a significance level of $a=0.05$ for hypothesis I and the Coefficient Determinations formula for hypothesis II. From the analysis it is known that the Professionalism of Class X Student Teachers at Madrasah Aliyah Muhammadiyah 02 Pondok Modern PaciranLamongan is in the "good enough" category. This is evidenced by the response of the largest respondents at intervals of 21-30 as many as 3 respondents (60\%), and the increase in student achievement of Class X students at Madrasah Aliyah Muhammadiyah 02 Pondok Modern PaciranLamongan in the "good enough" category. This conclusion is evidenced by the responses of the largest respondents at the interval 21-30, namely 16 respondents (53.3\%). While the results of the latest research state that teacher professionalism has a positive effect on the improvement of student achievement in class X class students at Madrasah Aliyah Muhammadiyah 02 Pondok Modern PaciranLamongan. This is evidenced by the calculated $r$ value (0.610)> $r$ table (0.334) at the significant level $a=0.05$. Thus it can be concluded that the alternative hypothesis ( $\mathrm{Ha}$ I which the author proposes says "there is a significant effect of Teacher Professionalism on the Improvement of Class X Student Achievement at Madrasah Aliyah Muhammadiyah 02 Pondok Modern PaciranLamongan", is proven true or "accepted". While the magnitude of the influence of Teacher Professionalism on the Improvement of Student Achievement in Class X is less than 0.50 (50\%), which is 0.3721 (37.21\%), although less than 50\% of the second hypothesis that the author proposes is proven to be true or "accepted".
\end{abstract}

Keywords: Teacher Professionalism, Improved Student Learning Achievement

\section{Pendahuluan}

Proses interaksi belajar mengajar merupakan suatu proses yang mengandung serangkaian perbuatan guru dan siswa atas timbal balik yang langsung dalam situasi pendidikan untuk mencapai tujuan tertentu. Interaksi guru dengan siswa bukan hanya dalam penguasaan bahan 
ajara, tetapi juga dalam penerimaan nilai-nilai, pengembangan sikap serta mengatasi kesulitaankesulitan yang di hadapi oleh siswa. Dengan demikian di dalam interaksi belajar mengajar dalam rangka menimbulkan motivasi belajar siswa, guru bukan hanya saja sebagai pelatih dan pengajar tetapi juga sebagai pendidik dan pembimbing (R. Ibrahim, Nana Syaodih S., 1996, p.33).

Oleh karena itu untuk mendukung terwujudnya suasana proses belaja rmengajar yang berkualitas di Sekolah, yang akan membawa peningkatan prestasi belajar siswa, diperlukan adanya guru yang profesional. Dalam menjalankan tugasnya, seorang guru profesional setidaknya harus memiliki kemampuan dan sikap sebagai berikut:

1. Menguasai kurikulum

2. Menguasai materi setiap mata pelajaran

3. Menguasai metode dan Evaluasi belajar

4. Setia terhadap tugas

5. Disiplin dalam arti yang luas (Zainal Aqib, 2002).

Menjadi guru profesional memang tidaklah mudah, mereka diharapkan menjunjung tinggi martabat manusia dari pada kepentingan pribadinya. Guru harus bersifat terbuka kepada semua anak didik, dalam menanggapi pertanyaan atau permasalahan anak didik, baik permasalahan pribadinya atau masalah pembelajaran. Disamping itu pengembangan profesinya sebagai guru sangatlah dibutuhkan, karena guru yang professional selalu mengembangkan profesinya demi menghadapi perkembangan zaman, terutama pada bidang keahliannya.

Dengan prestasi belajar siswa yang meningkatkan suasana pembelajaran yang aktif dan kreatif. Sehingga semakin banyak siswa aktif dalam belajar, makin tinggilah kemungkinan prestasi belajar yang dicapainya. Sebaliknya semakin banyak siswa yang pasif maka kemungkinan prestasi belajar akan menurun.

Dengan demikian profesionalisme guru yang tinggi sangatlah dibutuhkan demi meningkatkan prestasi belajar siswa. Oleh karena itu sebagai guru yang professional hal-hal yang harus diperhatikan dalam meningkatkan prestasi belajar siswa adalah sebagai berikut:

a. Peningkatan pada aspekkognitif

b. Peningkatan pada aspekafektif

c. Peningkatan pada aspekkognitifpsikomotorik

Seperti yang termaktubdalamdalam Al-Qur'an surat Al-Mujadalahayat 11: 
Artinya: Wahai orang-orang yang beriman! Apabila dikatakan kepada kamu "Berilah kelapangan di dalam Majelis", maka lapangkanlah, niscaya Allah akan memberikan kelapangan untukmu. Dan apabila dikatakan"Berdirilah kamu", maka berdirilah. Niscaya Allah akan mengangkat (derajat) orang-orang yang beriman di antara kamu dan orang-orang yang diberi ilmu pengetahuan beberapa derajat. Dan Allah Maha teliti apa yang kamu kerjakan (QS. AlMujadalah : 11).

Adapun untuk meningkatkan kreativiatas guru dalam mengajar hendaknya guru mau merencanakan program pengajaran dan sekaligus mampu pula melaksanakannya dalam bentuk pengelolaan kegiatan belajar mengajar. Bila guru berhasil melaksanakan dengan baik, akan tampak perubahan-perubahan yang berarti pada siswa-siswinya, antara lain timbul sikap positif dalam belajarnya dan prestasi belajarnya meningkat.

Bagi guru sendiri keberhasilan tersebut akan meningkatkan rasa percaya diri dan semangat mengajar yang tinggi. Hal ini merupakan keterampilan dasar mengajar yang perlu dibina dan dikembangkan sehingga ia menjadi guru yang benar-benar kreatif dan berprofesi dalam bidang keguruan.

Berdasarkan latar belakang di atas maka penulis memilih judul penelitian: "Pengaruh Profesionalisme Guru Terhadap Peningkatan Prestasi Belajar Siswa Kelas X Di MAM 02 Pondok Modern Paciran Lamongan”

\section{Rumusan Masalah}

1. Bagaimana profesionalisme Guru di MAM 02 Pondok Modern Paciran Lamongan?

2. Bagaimana peningkatan prestasi belajar siswa kelas X di MAM 02 Pondok Modern Paciran Lamongan?

3. Bagaimana pengaruh profesionalisme Guru terhadap peningkatan prestasi belajar siswa kelas X di MAM 02 Pondok Modern Paciran Lamongan?

\section{Landasan Teori}

\section{Pengertian profesionalisme Guru}

Kata "Profesionalisme" berasal dari kata bahasacInggris professionalism yang secara leksikal berarti sifat profesional (Sudarwan Danim, 2008). Orang professional memiliki sikap yang berbeda, meskipun mereka mengerjakan pekerjaan yang sama, akan tetapi hasilnya 


\section{Himmatul Husniyah}

berbeda. Tidak jarang orang yang berlatarbelakang pendidikan sama menampilkan kinerja profesional yang berbeda, tergantung banyak orang yang menilainya.

Sedangkan yang dimaksud guru dalam hal ini adalah sebagai seorang pendidik dan merupakan sosok manusia yang menjadi panutan bagian anak didiknya dan juga merupakan sebagai penentu arah bagi kemajuan suatu bangsa. Hal ini sebagaimana dijelaskan bahwa guru adalah orang yang memiliki kemampuan untuk mengajar atau orang yang pekerjaannya (mata pencahariannya, profesinya) mengajar" (lihat Departemen Pendidikan Nasional, 2001).

Jadi guru adalah orang yang mendidik dan menagajar kepada siswa untuk mengarahkan peserta didik dalam kehidupan yang akan datang yang lebih baik. Jabatan guru dikenal sebagai suatu pekerjaan profesional, artinya jabatan ini memerlukan keahlian khusus untuk menguasai bidang ilmu yang secara sengaja harus dipelajari dan kemudian diaplikasikan bagi kepentingan umum. Artinya setiap guru professional harus menguasai pengetahuan yang mendalam dalam spesialisasinya.

Penguasaan pengetahuan ini merupakan syarat yang penting di samping keterampilanketerampilan lain. Guru profesional selain menguasi seluk-beluk pendidkan dan pengajaran serta ilmu-ilmu lainya, guru juga dibekali pendidikan khusus untuk menjadi guru dan memiliki keahlian khusus yang diperlukan sesuai dengan profesinya.

Karakteristik guru yang profesional sedikitnya ada lima karakteristik dan kemampuan profesional guru yang harus dikembangkan, yaitu:

a. Menguasai kurikulum

b. Menguasai materi semua mat apelajaran

c. Terampil menggunakan multi metode pembelajaran

d. Memiliki komitmen yang tinggi terhadap tugasnya

e. Memiliki kedisiplinan dalam arti yang seluas-luasnya (Departemen Pendidikan Nasional, 2001).

Selanjutnya dari hasil studi para ahli mengenai sifat atau karakteristik profesi guru itu disimpulkan sebagai berikut:

a. Kemampuan yang diperoleh melalui pendidikan akademik

Pendidikan yang dimaksud adalah jenjang pendidikan tinggi. Selain itu, kemampuan intelektual didapat pula dari pelatihan khusus yang berkaitan dengan keilmuan yang dimiliki oleh seorang penyandang profesi. 


\section{Pengaruh Profesionalisme Guru Terhadap}

Peningkatan Prestasi Belajar Siswa

b. Memiliki pengetahuan spesialisasi

Pengetahuan spesialisasi adalah sebuah kekhusususan penguasaan bidang keilmuan tertentu. Siapa saja bisa menjadi "guru", tetapi guru yang sesungguhnya memiliki spesialisasi bidang studi (subject matter) dan penguasaan metodologi pembelajaran.

c. Memiliki pengetahuan praktis yang dapat digunakan langsung oleh orang lain atau klien Pengetahuan itu bersikap aplikatif. Aplikasi ini didasarkan atas kerangka yang jelas dan teruji. Makin spesialisasi seseorang, makin mendalam pengetahuannya dibidang itu dan makin akurat pula layanannya pada klien.

d. Memiliki teknik kerja yang dapat dikomunikasikan (communicable)

Seorang guru harus mampu berkomunikasi sebagai guru dalam makna apa yang disampaikannya dapat difahami oleh peserta didik.

e. Memiliki kapasitas mengorganisasikan kerja secara mandiri (self organization)

Istilah mandiri disini kewenangan akademiknya melekat pada dirinya. Pekerjaannya dapat dikelola sendiri, tanpa bantuan orang lain, meski tidak menafikan bantuan atau mereduksi semangat kolegialitas.

f. Mementingkan kepentingan orang lain (altruism)

Seorang guru harus siap memberikan layanan kepada anak didiknya pada saat bantuan diperlukan, baik di kelas, di lingkungan sekolah maupun di luar sekolah sekalipun dia sedang istirahat.

\section{g. Memiliki kode etik}

Kode etik ini merupakan norma-norma yang mengikat guru dalam bekerja, misalnya pada saat proses belajar mengajar. Bukan berarti kode etik tersebut dalam aplikasinya hanya sebatas ketika guru sedang bekerja, akan tetapi harus diaplikasikan dalam kehidupan sehari-hari. Hal ini disebabkan karena disamping sebagai pengajar, guru merupakan panutan bagi anak didik dan masyarakat sekitarnya.

\section{Syarat-Syarat Dan Kompetensi Guru}

"Proses interaksi belajar mengajar merupakan suatu proses yang mengandung serangkaian perbuatan guru dan siswa atas timbal balik yang langsung dalam situasi pendidkan untuk mencapai tujuan tertentu. Intraksi guru dengan siswa bukan hanya dalam penguasaan bahan ajara, tetapi juga dalam penerimaan nilai-nilai, pengembangan sikap serta mengatasi kesulitaan-kesulitan yang dihadapi oleh siswa. Dengan demikian didalam intraksi belajar 
mengajar dalam rangka menimbulkan motivasi belajar siswa, guru bukan hanya saja sebagai pelatih dan pengajar tetapi juga sebagai pendidik dan pembingbing" (R. Ibrahim, Nana Syaodih S., 1996, p.33)

Menurut Daradjat, dalam Djamarah (2000: p.32) bahwa untuk menjadi guru harus memenuhi persyaratan seperti:

a. Taqwa kepada Allah SWT

b. Berilmu

c. Sehat jasmani

d. Berkelakuan baik (R. Ibrahim, Nana Syaodih S., 1996, p.33)

Sedangkan menurut H. Mubangid bahwa syarat-syarat untuk menjadi pendidik yaitu:

a. Dia harus orang yang beragama

b. Mampu bertanggungjawab atas kesejahteran agama.

c. Dia tidak kalah dengan guru-guru sekolah lainnya dalam membetuk negara yang demokratis dan bertanggungjawab atas kesejahteraan bangsa dan tanah air.

d. Dia harus memiliki perasaan panggilan murni (roeping) (Ahmadi, Abu dan Nur Uhbaiti, 1991, p.74).

Syarat yang dikemukakan di atas dapat dipahami bahwa pendidik atau guru adalah orang dewasa yang berakhlak baik dan mempunyai kecakapan mendidik. Mengingat tugas dan tanggungjawab yang begitu kompleksnya, maka profesi ini memerlukan persayaratan khusus, yang menurut Ali (1985) untuk menjadi guru professional persyaratan yang harus dipenuhi adalah :

a. Menuntut adanya keterampilan yang berdasarkan konsep dan teori ilmu pengetahuan yang mendalam.

b. Menekankan pada suatu keahlian dalam bidang tertentu sesuai dengan profesinya.

c. Menuntut adanya tingkat pendidikan keguruan yang memadai

d. Adanya kepekaan terhadap dampak kemasyarakat dari pekerjaan yang dilaksanakannya

e. Memungkinkan perkembangannya sejalan dengan dinamika kehidupan

Adapun kompetensi yang harus dimiliki seorang guru itu mencakup empat aspek sebagai berikut:

a. Kompetensi Pedagogik. 


\section{Pengaruh Profesionalisme Guru Terhadap Peningkatan Prestasi Belajar Siswa}

Dalam Standar Nasional Pendidikan, penjelasan Pasal 28 ayat (3) butir dikemukakan bahwa kompetensi pedagogik adalah kemapuan mengelola pembelajaran peserta didik yang meliputi pemahaman terhadap peserta didik, perancangan dan pelaksanaan pembelajaran, evaluasi hasil belajar, dan pengembangan peserta didik untuk mengaktualisasikan berbagai potensi yang dimilikinya (E. Mulyasa, 2008).

b. Kompetensi Kepribadian.

Dalam Standar Nasional Pendidikan, penjelasan Pasal 28 ayat (3) butir dikemukakan bahwa yang dimaksud dengan kompetensi kepribadian adalah kemampuan kepribadian yang mantap, stabil,dewasa, arif, dan berwibawa, menjadi teladan bagi peserta didik, danberakhlak mulia.

c. Kompetensi Profesioanal.

Dalam Standar Nasional Pendidikan, penjelasan Pasal 28 ayat (3) butir dikemukakan bahwa yang dimaksud kompetensi profesional adalah kemampuan penguasaan materi pembelajaran secara luas dan mendalam yang memungkinkan membimbing peserta didik memenuhi standar kompetensi yang ditetapkan dalam Standar Nasional Pendidikan.

d. Kompetensi Sosial.

Dalam Standar Nasional Pendidikan, penjelasan Pasal 28 ayat (3) butir dikemukakan bahwa yang dimaksud dengan kompetensi sosialadalah kemampuan guru sebagai bagian dari masyarakat untuk berkomunikasi dan bergaul secara efektif dengan peserta didik, sesama pendidik, tenaga kependidikan, orang tua/wali peserta didik, dan masyarakat sekitar.

Sejalan dengan kutipan di atas, maka profesionalitas guru adalah rangka motivasi siswa untuk sukses dalam belajar akan terlihat dengan kemampuan di dalam interaksi belajar mengajar yang muncul indikator penggunaan metode dan media yang bervariasi, pemilihan bahan yang menarik minat, pemberian kesempatan untuk sukses, penyajian suasana belajar mengajar yang menyenangkan dan juga pengadaan persaingan sehat.

Bila profesionalitas guru yang memiliki indikator seperti diatas direalisasikan di dalam intraksi belajar mengajar maka siswa akan aktif mengikuti intraksi belajar mengajar, menyelesaikan tugas-tugas dengan penuh kesadaran, mudah memahami materi yang diajarkan oleh guru. Pada kondisi yang seperti itu maka kesuksesan belajar dapat tercapai secara maksimal. 


\section{Tugas Dan Peran Guru Dalam Proses Belajar Mengajar}

Menurut Suryosubroto peran dan tugas guru sebagai pendidik professional sebenarnya sangat kompleks, tidak terbatas pada saat berlangsungnya interaksi edukatif di dalam kelas, yang lazim disebut proses belajar mengajar. Guru juga bertugas sebagai administrator, evaluator, konselor dan lain-lain sesuai dengan sepuluh kompetensi (kemampuan) yang dimilikinya (B. Suryosubroto, 1997)..

Tugas guru dalam proses belajar mengajar meliputi tugas paedagogis dan administrasi. Tugas paedagogis adalah tugas membantu, membimbing dan memimpin. Moh. Rifai mengatakan bahwa:

"Di dalam situasi pengajaran, gurulah yang memimpin dan bertanggungjawab penuh atas kepemimpinan yang dilakukan itu. Ia tidak melakukan intruksi-intruksi dan tidak di bawah intruksi manusia lain kecuali dirinya sendiri, setelah masuk dalam situasi kelas”.

Jadi setelah masuk kelas tugas seorang guru tidak hanya sekedar menyampaikan materi pelajaran saja, akan tetapi guru juga memimpin dan bertanggung jawab penuh pada anak didiknya pada proses belajar mengajar.

Proses belajar mengajar merupakan inti dari proses pendidikan secara keseluruhan dengan guru sebagai pemegang peranan utama. Karena Proses belajar-mengajar mengandung serangkaian perbuatan pendidik/guru dan siswa atas dasar hubungan timbal balik yang berlangsung dalam situasi edukatif untuk mencapai tujuan tertentu. Interaksi atau hubungan timbal balikantara guru dan siswa itu merupakan syarat utama bagi berlangsungnya proses belajar-mengajar. Interaksi dalam peristiwa belajar-mengajar ini memiliki arti yang lebih luas, tidak sekedar hubungan antara guru dengan siswa, tetapi berupa interaksi edukatif. Dalam hal ini bukan hanya penyampaian pesan berup amateri pelajaran, melainkan menanamkan sikap dan nilai pada diri siswa yang sedang belajar.

Peran guru dalam proses belajar mengajar, guru tidak hanya tampil lagi sebagai pengajar (teacher), seperti fungsinya yang menonjol selama ini, melainkan beralih sebagai pelatih (coach), pembimbing (counselor) dan manager belajar (learning manager). Hal ini sudah sesuai dengan fungsi dari peran guru masa depan. Di mana sebagai pelatih, seorang guru akan berperan mendorong siswanya untuk menguasai alat belajar, memotivasi siswa untuk bekerja keras dan mencapai prestasi setinggi-tingginya. 


\section{Pengaruh Profesionalisme Guru Terhadap}

Peningkatan Prestasi Belajar Siswa

Kehadiran guru dalam proses belajar mengajar atau pengajaran, masih tetap memegang peranan penting. Peranan guru dalam proses pengajaran belum dapat digantikan oleh mesin, radio, tape recorder ataupun oleh komputer yang paling modern sekalipun. Masih terlalu banyak unsur-unsur manusiawi seperti: sikap, sistem, nilai, perasaan, motivasi, kebiasaan dan Iain-lain yang diharapkan merupakan hasil dari proses pengajaran, tidak dapat dicapai melalui alat-alat tersebut. Disinilah kelebihan manusia dalam hal ini guru dari alat-alat atau teknologi yang diciptakan manusia untuk membantu dan mempermudah kehidupannya.

Dengan demikian dalam system pengajaran mana pun, guru selalu menjadi bagian yang tidak terpisahkan, hanya peran yang dimainkannya akan berbeda sesuai dengan tuntutan system tersebut. Dalam pengajaran atau proses belajar mengajar guru memegang peran sebagai sutradara sekaligus aktor. Artinya, pada gurulah tugas dan tanggungjawab merencanakan dan melaksanakan pengajaran di sekolah.

Sebagaimana telah di ungkapkan di atas, bahwa peran seorang guru sangatlah signifikan dalam proses belajar mengajar. Peran guru dalam proses belajar mengajar banyak hal seperti: sebagai pengajar, manajer kelas, supervisor, motivator, konsuler, eksplorator, dsb. Yang akan dikemukakan disini adalah peran yang dianggap paling dominan dan klasifikasi guru sebagai: demonstrator, manajer/pengelolakelas, mediator/fasilitator dan evaluator:

\section{a. Guru Sebagai Demonstrator}

Melalui peranannya sebagai demonstrator, lecturer, atau pengajar, guru hendaknya senantiasa menguasai bahan atau materi pelajaran yang akan diajarkannya serta senantiasa mengembangkannya dalam arti meningkatkan kemampuannya dalam hal ilmu yang dimilikinya karena hal ini akan sangat menetukan hasi lbelajar yang dicapai oleh siswa. Salah satu hal yang harus diperhatikan oleh guru ialah bahwa ia sendiri adalah pelajar. Ini berarti bahwa guru harus belajar terus-menerus. Dengan cara demikian ia akan memperkaya dirinya dengan berbagai ilmu pengetahuan sebagai bekal dalam melaksanakan tugasnya sebagai demonstrator sehingga mampu memperagakan apa yang diajarkannya secara didaktis. Maksudnya ialah agar apa yang disampaikannya itu betulbetul dimiliki oleh anak didik.

b. Guru Sebagai Pengelola Kelas

Mengajar dengan sukses berarti harus ada keterlibatan siswa secara aktif untuk belajar. Keduanya berjalan seiring, tidak ada yang mendahului antara mengajar dan belajar karena 
masing-masing memiliki peran yang memberikan pengaruh satu dengan yang lainnya. Keberhasilan/kesuksesan guru mengajar ditentukan oleh aktivitas siswa dalam belajar, demikian juga keberhasilan siswa dalam belajar ditentukan pula oleh peran guru dalam mengajar.

Belajar adalah kegiatan individu memperoleh pengetahuan, perilaku, dan keterampilan dengan cara mengolah bahan belajar. Proses belajar mengajar akan berlangsung dengan baik jika guru dan siswa sama-sama mengerti bahan apa yang akan dipelajari sehingga terjadi suatu interaksi yang aktif dalam PBM di kelas dan hal ini menjadi kunci kesuksesan dalam mengajar.

c. Guru sebagai mediator dan fasilitator

Sebagai mediator guru hendaknya memiliki pengetahuan dan pemahaman yang cukup tentang media pendidikan karena media pendidikan merupakan ala tkomunikasi guna lebih mengefektifkan proses belajar-mengajar. Dengan demikian jelaslah bahwa media pendidikan merupakan dasar yang sangat diperlukan yang bersifat melengkapi dan merupakan bagian integral demi berhasilnya proses pendidikan.

Sebagai fasilitator guru hendaknya mampu mengusahakan sumber belajar yang kiranya berguna serta dapat menunjang pencapaian tujuan dan proses belajar-mengajar, baik yang berupa nara sumber, buku teks, majalah ataupun surat kabar.

d. Guru sebagai evaluator

Dalam dunia pendidikan, setiap jenis pendidikan atau bentuk pendidikan pada waktuwaktu tertentu selama satu periode pendidikan akan diadakan evaluasi, artinya pada waktuwaktu tertentu selama satu periode pendidikan tadi orang selalu mengadakan penilaian terhadap hasil yang telah dicapai, baik oleh pihak terdidik maupun oleh pendidik. Penilaian perlu dilakukan, karena dengan penilaian guru dapat mengetahui keberhasilan pencapaian tujuan, penguasaan siswa terhadap pelajaran, serta ketepatan atau keefektifan metode mengajar. Dalam melaksanakan evaluasi atau penilaian, pendidik harus memperhatikan tiga aspek yang meliputi: aspek kognitif, afektif dan psikomotorik anak didik.

\section{Upaya Guru Agama Dalam Meningkatkan Prestasi Belajar Siswa}

a. Mengadakan Persiapan Mengajar 


\section{Pengaruh Profesionalisme Guru Terhadap Peningkatan Prestasi Belajar Siswa}

Persiapan mengajar merupakan langkah pertama yang harus diperhatikan oleh seorang guru, sebab berhasil tidaknya seorang guru menyampaikan bahan pelajaran tergantung pada siap tidaknya sipenyampai sendiri.

Adapun yang dimaksud dengan persiapan mengajar adalah suatu perencanaan pemikiran yang sistematis berupa prinsip-prinsip mengajar, yang akan diterapkan dalam suatu situasi khusus dalam pengajaran di kelas. Semakin baik persiapan mengajar, maka semakin baik pula hasil yang akan diperoleh atau dicapai (TayarYusuf, Syaiful Anwar, 1995).

Persiapan mengajar dewasa ini sering juga disebut dengan istilah satuan pelajaran, yang popular disebut "SP" yang termuat dalam SP adalah sebagai berikut:

1) Persiapanterhadapsituasiumum

2) Persiapan terhadap murid yang akan dihadapi

3) Persiapan terhadap tujuan yang akan dicapai

4) Persiapan terhadap metode mengajar yamg digunakan

5) Persiapan terhadap bahan yang akan diajarkan

6) Persiapanterhadapalat-alatpembantuatau media pengajaran

7) Persiapan terhadap teknik-teknik evaluasi mengajar (WinarnoSurkhmad, 1980, p.127)

b. MemberikanMotivasiBelajar

Motivasi yang dimaksud disini adalah suatu keadaan dalam diri anak, yang mendorong individu untuk melakukan aktivitas-aktivitas tertentu guna mencapai tujuan yang dicitacitakan.

Adapun bentuk dan cara menumbuhkan motivasi ini antara lain:

1) Pemberian pujian karena telah berhasil menyelesaikan tugasnya dengan baik.

2) Pemberian hukuman atau sangsi, yakni hal ini harus dilakukan dengan tepat dan bijak, selain itu juga hukuman tersebut harus bertujuan untuk memperbaiki sikap dan perbuatan siswa yang dianggap salah

3) Penghormatan Ada dua jenis penghormatan, yaitu :

a) Berbentuk semacam penobatan, yaitu anak yang akan mendapatkan penghormatan diumumkan dan ditampilkan dihadapan teman-teman sekelasnya

b) Berbentuk pemberian kekuasaan. Misalnya, anak yang berhasil menyelesaikan tugas yang sulit disuruh mengerjakan soal dipapan tulis untuk dicontoh temantemannya.

4) Pemberian hadiah bagi yang berprestasi 
5) Pemberian tanda penghargaan yang biasa disebut ganjaran simbolis (dinilai dari segi kesan), yakni ganjaran yang berupa surat-surat tanda penghargaan, surat-surat tanda jasa, sertifikat dan lain-lain.

c. Menggunakan metode mengajar yang tepat dan bervariasi

Metode mengajar adalah salah satu metode yang digunakan dalam proses belajar mengajar untuk mencapai tujuan pembelajaran. Agar tujuan itu dapat tercapai secara efektif dan efisien, selain menguasai bahan materi, maka seorang guru harus menguasai teknik atau metode penyampain materi yang tepat dalam proses belajar mengajar sesuai dengan materi yang diajarkan dan kemampuan anak didik yang menerima. Mampu memilih dan menggunakan metode yang tepat merupakan kemampuan dasar guru yang paling utama dalam meraih sukses belajar disekolah. Guru yang tidak mengenal metode mengajar, jangan diharap dapat melaksanakan tugas mengajar sebaik-baiknya.

Dengan demikian beberapa upaya yang dapat dilakukan guru agama dalam rangka menumbuhkan minat belajar siswa sehingga dapat meningkatkan prestasi belajar siswa. Kalau dikaji lebih luas lagi tentunya tidak cukup tiga hal diatas, sedangkan pembahasan yang ditulis disini hanya sekedar memberikan sebagian kecil gambaran secara teoritik belaka.

\section{Prestasi Belajar}

Prestasi belajar berasal dari bahasa Belanda yaitu prestasie yang kemudian dalam bahasa Indonesia menjadi prestasi yang berarti hasil usaha (Zainal Arifin, 1990, p.2). Kata prestasi banyak digunakan dalam berbagai bidang dan kegiatan, antara lain dalam kesenian, olahraga , pendidikan dan pengajaran. Menurut .Djalimus Syah prestasi mempunyai arti hasil yang diperoleh dari kerja keras yang dilakukan oleh seseorang (Djalinus Syah, P.168)

Sedangkan menurut James S Cangelosi, prestasi adalah tingkat kemajuan yang telah dicapai seseorang hasil yang dicapai atau dilakukan (Muhaimin, Abdul Ghafir, Nur Ali Rahman, 1996, p.45)

Dari penjelasan diatas dapat disimpulkan bahwa prestasi adalah hasil kemampuan atau ketrampilan seseorang dalam melakukan suatu aktifitas atau pekerjaan secara maksimal. Sedangkan belajar, Nasution, mengemukakan, belajar sering dirumuskan sebagai perubahan kelakuan-kelakuan yang meliputi pengamatan, persiapan, minat, sikap dsb (Nasution, 1982, p.71). 
Menurut Muhaimin, dalam bukunya "Strategi Belajar" mengemukakan pengertian belajar adalah aktivitas yang menghasilkan perubahan pada diri individu yang belajar baik itu aktual maupun potensial.

Dengan demikian maka belajar adalah usaha seseorang untuk membimbing dirinya kedalam perubahan situasi menuju tingkah laku yang akan dicapai oleh siswa. Jadi, prestasi belajar siswa adalah suatu hasil aktifitas atau pekerjaan secara maksimal yang dicapai oleh siswa dalam perubahan situasi tingkah lakunya.

\section{Fungsi dan Kegunaan Prestasi Belajar}

Semua usaha yang dilakukan oleh seseorang, apapun itu bentuknya tentu mempunyai fungsi dan kegunaan, hanya saja fungsi dan kegunaan itu pasti berbeda menurut bidangnya masing-masing, begitu pula masalah prestasi belajar.

Menurut Zainal Arifin, prestasi belajar semakin terasa penting dibahas karena mempunyai fungsi utama, antara lain:

a. Prestasi belajar sebagai indikator kualitas dan kuantitas pengetahuan yang telah dikuasai oleh anak didik

b. Prestasi belajar sebagai lambing pemuasan hasrat ingin tahu, hal ini didasarkan atas asumsi bahwa para ahli psikologi biasanya menyebut hal ini sebagai tendensi keingintahuan dan merupakan kebutuhan umum pada manusia termasuk pada anak didik dalam suatu program pendidikan.

c. Prestasi belajar sebagai bahan informasi dalam inovasi pendidikan. Asumsinya adalah bahwa prestasi belajar dapat dijadikan pendorong bagi anak dalam meningkatkan ilmu pengetahuan dan teknologi dan berperan sebagai umpan balik dalam meningkatkan mutu pendidikan.

d. Prestasi belajar sebagai indikator intern dan ekstern dari suatu institusi pendidikan.

e. Prestasi belajar sebagai indikator terhadap daya serap kecerdasan anak didik.

Dengan mengetahui beberapa fungsi prestasi belajar tersebut, maka dipandang perlu kita menguraikan prestasi anak didik itu secara individu maupun kelompok, karena fungsi belajar tidak hanya sebagai indikator kualitas institusi pendidikan saja, disamping itu prestasi belajar juga berguna bagi umpan balik guru dalam melaksanakan proses balajar mengajar yang akhirnya dapat menentukan apakah perlu mengadakan diagnosis bimbingan atau penempatan terhadap anak didik 
Dalam kaitannya dengan kegunaannya, mengetahui tentang prestasi belajar siswa, Cronbach memberikan komentar bahwa kegunaan prestasi belajar banyak ragamnya tergantung pada ahli dan versinya masing-masing, namun diantaranya adalah sebagai berikut:

a. Sebagai umpan balik bagi pendidik dalam mengajar

b. Untuk keperluan diagnosis

c. Untuk keperluan bimbingan dan penyuluhan

d. Untuk keperluan seleksi

e. Untuk keperluan penjurusan

f. Untuk menentukan isi kurikulum

g. Untuk menentukan kebijaksanaan sekolah.

Yang perlu diingat bahwa prestasi anak didik tidak mutlak merupakan cermin dari kecerdasan dan kemampuan yang dimiliki, melainkan hal itu ada faktor yang mempengaruhinya sebab kecakapan dan kecerdasan yang dimiliki anak didik itu merupakan unsur dalam pembentukan prestasi.

Dengan kata lain bahwa kecerdasan dan kecakapan anak didik yang tinggi bukanlah jaminan mutlak untuk terciptanya prestasi yang tinggi. Begitu pula sebaliknya prestasi belajar yang rendah tidak mutlak didasari oleh kecerdasan yang rendah, melainkan faktor yang mempengaruhinya, baik faktor intern maupun ekstern.

\section{Faktor yang Mempengaruhi Prestasi Belajar}

Untuk mengetahui factor apa saja yang mempengaruhi prestasi atau keberhasilan siswa dalam belajar tentunya banyak ragamnya. Suryadi Suryabrata dalam buku "Proses Belajar Mengajar di Perguruan Tinggi” membagi dalam duaf aktor, yaitu factor luar dan factor dalam.

Dalam melaksanakan proses belajar mengajar, perlu diperhatikan adanya faktor-faktor yang mempengaruhi terhadap keberhasilan belajar siswa. Faktor-faktor tersebut ada 5 macam yang kesemuanya mempunyai hubungan yang erat. Kelima factor tersebut adalah:

a. Faktor Anak Didik

Faktor anak didik merupakan faktor pandidikan yang penting, sebab tanpa anak didik kegiatan pendidikan tidak akan berlangsung. Faktor dalam diri anak didik sangat berpengaruh dalam keberhasilan atau pencapaian prestasi belajar siswa. Faktor dalam diri anak tersebut seperti kemampuan intelegensi, keadaan jasmani dan keadaan fisiologi dan psikologinya. 


\section{Pengaruh Profesionalisme Guru Terhadap}

Peningkatan Prestasi Belajar Siswa

\section{b. FaktorPendidik}

Hal ini sangat penting dalam rangka membawa anak kepada prestasi belajar yang lebih baik, hal ini akan banyak dipengaruhi oleh cara mengajar yang efektif, sehingga prestasi belajar siswa akan maksimal. Pendidik adalah orang yang bertanggungjawab terhadap anak didiknya yang mempunyai tugas mengajar pengetahuan, menanamkan keimanan dalam jiwa anak, mendidik agar anak taat menjalankan ajaran agama dan berakhlak mulia.

Tentang pertanggungjawaban seorang pemimpin, dalam hal ini seorang guru dalam alQur'an telah dijelaskan sebagai berikut:

Artinya: Setiap orang bertanggungjawab terhadap apa yang diperbuatnya (QS. At-Thur: 21).

c. FaktorTujuan Pendidikan

Faktor ini sangat menentukan terhadap berhasil atau tidaknya kegiatan proses belajar mengajar, khususnya pendidikan agama Islam, sebab tujuan itulah yang hendak dicapai oleh anak didik dalam kegiatan belajar, tanpa ada tujuan yang jelas, sulit untuk mengontrol sampai sejauh mana yang telah dicapai oleh anak didik.

d. Faktor Alat-Alat Pendidikan

Maksudnya adalah segala sesuatu yang digunakan dalam usaha untuk mencapai tujuan pendidikan agama berupa alat tulis, buku pelajaran, alat peraga dan lain-lain. Tanpa alatalat tersebut sulit prestasi belajar siswa dapat tercapai sesuai yang diharapkan.

e. Faktor Lingkungan

Faktor lingkungan sangat besar pengaruhnya terhadap keberhasilan tujuan pendidikan agama Islam, baik lingkungan keluarga, sekolah maupun masyarakat. Pengaruh tersebut dapat positif atau negatif. Keluarga lestari yang agamis dapat menjamin ketenangan psikologis dan social dalam hubungan orang dewasa dan anak-anak. Demikian juga cara hidup lingkungan disekitar rumah dimana anak tinggal, mempunyai pengaruh yang besar terhadap pertumbuhan dan perkembangan anak. Seandainya mereka di lingkungan yang rajin belajar, secara otomatis anak akan rajin belajar.

Dari kelima factor tersebut, sangatlah berpengaruh besar pada peningkatan prestasi siswa dalam ranah kognitif (intelektual siswa), afektif (sikap siswa), psikomotorik (penerapan siswa). 
Jadi, guru professional diharapkan memperhatikan kelima factor di atas dalam meningkatkan prestasi belajar siswa, sehigga para guru terutama guru Pendidikan Agama Islam (PAI) tidak salah arah dalam mengarahkan anak didiknya dalam mengembangkan ranah kognitif (intelektual siswa), afektif (sikap siswa), psikomotorik (penerapan siswa) baik dalam lingkungan keluarga, sekolah, dan masyarakat. Dengan demikian tidak akan keluar dari rel tujuan pendidikan agama Islam itu sendiri.

\section{Metode Penelitian}

\section{MetodePenelitian}

Dalam penelitian ini, penulis menggunakan jenis penelitian lapangan (Field Research) jika dilihat dari jenis masalahnya, penelitian ini bersifat kausal korelatif atau korelasi sebab akibat. Sesuai dengan rumusan masalah yang dikemukakan, maka penelitian ini bertujuan untuk mengidentifikasi ada atau tidaknya pengaruh dan apabila ada, bagaimana pengaruh profesionalisme Guru terhadap peningkatan prestasi belajar siswa kelas X di Madrasah Aliyah Muhammadiyah Pondok Modern Paciran Lamongan.

\section{Variabel Penelitian}

Dalam penelitian ini penulis menguji pengaruh profesionalisme guru terhadap peningkatan prestasi belajar siswa kelas X di Madrasah Aliyah Muhammadiyah 02 Pondok Modern Paciran Lamongan.

1. Variabel bebas dalam penelitian ini adalah Profesionalisme Guru

2. Variabelterikat dalam penelitian ini adalah peningkatan prestasi belajar siswa kelas $\mathrm{X}$

\section{Populasi dan Sampel}

Populasi

Populasi adalah totalitas dari objek penelitian yang dapat berupa manusia, hewan, tumbuh-tumbuhan dan benda yang mempunyai kesamaan sifat. Populasi merupakan kelompok besar yang menjadi objek penelitian (M. Musfiqon, 2012, p.89). Adapun dalam penelitian ini obyek penelitiannya adalah murid kelas Xdi Madrasah Aliyah Muhammadiyah 02 Pondok Modern Paciran Lamongan yang berjumlah 303 Siswa.

Sampel

Sampel adalah sebagian atau populasi yang diteliti (Suharismi Arikunto, 2010, p.174). salah satu syarat yang harus dipenuhi diantaranya adalah bahwa sampel harus diambil dari 
bagian populasi. Dalam penelitian ini sampel yang dimbil adalah populasi terjangkau. Berdasarkan survei yang telah dilakukan, di ketahui bahwa jumlah siswa Madrasah Aliyah Muhammadiyah 02 Pondok Modern Paciran Lamongan 303, maka penelita mengambil 30 sswa untuk diambil sampel.

\section{Hasil Dan Pembahasan}

\section{Uji Validitas dan Reliabilitas}

Uji validitas dan reliabilitas instrumen (angket) dalam penelitian ini dilakukan kepada 10 guru profesional dan 10 siswa kelas XMadrasah Aliyah Muhammadiyah 02 Pondok Modern Paciran Lamongan. Penentuan respoden sebagai uji validitas dan reliabilitas angket dilakukan secara acak (random sampling) dari 10 guru profesional dan 10 siswa kelas $\mathrm{X}$.

\section{Uji Validitas}

Sebuah instrumen dikatakan valid apabila mampu mengukur apa yang diinginkan dan dapat mengugkap data dari variabel yag diteliti secara tepat. Tinggi rendahnya validitas instrumen menunjukkan sejauh mana data terkumpul tidak menyimpang dari gambaran tentang variabel yang diteliti.

Validitas menunjukkan sejauh mana ketepatan dan kecermatan suatu alat ukur dalam melakukan fungsinya sebagai alat ukur, uji validitas yang digunakan dalam penelitian ini yaitu mengunakan Product Moment Pearson, dengan bantuan komputer program Statistical Package For The Social Science (SPSS) 12.00 for Windows.

Adapun ringkasan hasil perhitungan program yang dilakukan terhadap masing-masing responden seperti disajikan pada Tabel berikut ini:

Tabel: Ringkasan Hasil Validitas Angket Profesionalisme Guru

\begin{tabular}{|c|c|c|c|}
\hline $\begin{array}{c}\text { No } \\
\text { Item }\end{array}$ & $\begin{array}{c}\text { Total Korelasi } \\
\text { Product Moment } \\
\text { Karl Pearson }\end{array}$ & $\begin{array}{c}\text { Konsultasi r hitung } \\
\text { dengan r tabel } \\
(\boldsymbol{\alpha}=\mathbf{0 , 0 5}) \mathbf{N}=\mathbf{5}\end{array}$ & Keterangan \\
\hline 1. & 0,960 & $0,960>0,878$ & Valid \\
\hline 2. & 0,984 & $0,984>0,878$ & Valid \\
\hline 3. & 0,984 & $0,984>0,878$ & Valid \\
\hline 4. & 0,984 & $0,984>0,878$ & Valid \\
\hline
\end{tabular}




\begin{tabular}{|c|c|c|c|}
\hline 5. & 0,984 & $0,984>0,878$ & Valid \\
\hline 6. & 0,984 & $0,984>0,878$ & Valid \\
\hline 7. & 0,960 & $0,960>0,878$ & Valid \\
\hline 8. & 0,960 & $0,960>0,878$ & Valid \\
\hline 9. & 0,984 & $0,984>0,878$ & Valid \\
\hline 10. & 0,989 & $0,989>0,878$ & Valid \\
\hline
\end{tabular}

\section{Sumber: Data primer yang sudah diolah}

Tabel: Ringkasan Hasil Validitas Angket Peningkatan Prestasi Belajar Siswa Kelas X

\begin{tabular}{|c|c|c|c|}
\hline $\begin{array}{c}\text { No } \\
\text { Item }\end{array}$ & $\begin{array}{l}\text { Total Korelasi } \\
\text { Product } \\
\text { Moment Karl } \\
\text { Pearson }\end{array}$ & $\begin{array}{c}\text { Konsultasi } r \text { hitung } \\
\text { dengan } r \text { tabel } \\
(\alpha=0,05) N=10\end{array}$ & Keterangan \\
\hline 1. & 0,892 & $0,892>0,632$ & Valid \\
\hline 2. & 0,894 & $0,894>0,632$ & Valid \\
\hline 3. & 0,928 & $0,928>0,632$ & Valid \\
\hline 4. & 0,881 & $0,881>0,632$ & Valid \\
\hline 5. & 0,870 & $0,870>0,632$ & Valid \\
\hline 6. & 0,938 & $0,938>0,632$ & Valid \\
\hline 7. & 0,879 & $0,879>0,632$ & Valid \\
\hline 8. & 0,907 & $0,907>0,632$ & Valid \\
\hline 9. & 0,860 & $0,860>0,632$ & Valid \\
\hline 10. & 0,894 & $0,894>0,632$ & Valid \\
\hline
\end{tabular}

Sumber : Data primer yang sudah diolah.

Berdasarkan uji validitas tabel diatas maka :

1) Variabek $X$ (Profesionalisme Guru) terdiri dari 10 item pertanyaan angket, ternyata semuanya valid, tidak ada yang tidak valid. 
2) Variabel Y (Peningkatan Prestasi Belajar Siswa Kelas X) terdiri dari 10 item pertanyaan angket yang semuanya valid.

Jadi dapat disimpulkan bahwa item pertanyaan dengan jumlah 20 itemdiatas, semuanya valid $(100 \%)$.

\section{Uji Reliabilitas}

Reliabilitas adalah indek yang menunjukkan sejauhmana suatu alat pengukur dapat dipercaya atau diandalkan,bila suatu alat ukur (kuesioner) dipakai dua kali untuk mengukur gejala yang sama dan hasil yang diperoleh relatif konsisten, maka alat tersebut reliabel. Dengan kata lain reliabilitas menunjukkan konsistensi suatu alat pengukur di dalam mengukur gejala yang sama.

Adapun teknik yang digunakan dalam penelitian ini adalah teknik Spearman Brown, di mana lankah-langkah ujinya adalah dengan mengelompokkan skor butir bernomor ganjil sebagai belahan pertama dan kelompok skor butir bernomor genap sebagai belahan kedua. Langkah selanjutnya adalah mengkorelasikan skor belahan pertama dengan skor belahan kedua dan diperoleh harga $r_{x y}$.

Tabel: Ringkasan Uji Reliabilitas Angket

\begin{tabular}{|c|c|c|c|c|}
\hline No & $\begin{array}{c}\text { Jumlah } \\
\text { Item }\end{array}$ & Variabel & $\begin{array}{c}\text { Reliability } \\
\text { Spearman's rho }\end{array}$ & Keterangan \\
\hline 1. & 10 & $\begin{array}{c}\text { Profesionalisme } \\
\text { Guru }\end{array}$ & $0,861>0,514$ & Valid \\
\hline 2. & 10 & $\begin{array}{c}\text { Prestasi Belajar } \\
\text { Siswa }\end{array}$ & $0,821>0,514$ & Valid \\
\hline
\end{tabular}

Sumber : Data primer yang sudah diolah

Dari Tabel di atas menunjukkan nilai spearman's rhovariabel profesionalisme guru (X) dan variabel prestasi belajar siswa (Y) mempunyai nilai lebih besar dari $0,514(\mathrm{~N}=15$ dan $\alpha=$ 0,05) dengan demikian seluruh seluruh item dianggap reliabel dalam melakukan fungsinya sebagai alat ukur.

\section{Pembahasan}

Dalam penelitian ini ada 2 variabel yaitu: variabel X (Profesionalisme Guru) dan variabel Y (Prestasi Belajar Siswa). Untuk mengetahui sampai dimana pengaruh Profesionalisme Guru 
Terhadap Peningkatan Prestasi Belajar Siswa Kelas X di Madrasah Aliyah Muhammadiyah 02 Pondok Modern Paciran Lamongan. maka penulis uraikan data-data sebagai berikut :

Data yang disajikan adalah data yang diperoleh melalui angket yang disebarkan 10 responden guru profesional. Angket ini terdiri dari 10 item, setiap soal disediakan 4 alternatif jawaban dengan ketentuan, jawaban A bernilai 4, jawaban B bernilai 3, jawaban C bernilai 2, dan jawaban D bernilai 1. Untuk lebih jelasnya penulis menyajikan jawaban siswa sebagaimana tabulasi data penelitian terlampir.

Berdasarkan tanggapan responden terhadap profesionalisme guru pada lampiran tabulasi data hasil penelitian, maka dapat diklasifikasikan sebagaimana Tabel dibawah ini:

Tabel: Tanggapan Responden Terhadap Profesionalisme Guru

\begin{tabular}{|c|c|c|c|c|}
\hline No & Interval Nilai & Frekuensi & Persentase & Keterangan \\
\hline 1. & $31-40$ & 1 & $20 \%$ & Baik \\
\hline 2. & $21-30$ & 3 & $60 \%$ & Cukupbaik \\
\hline 3. & $11-20$ & 3 & $60 \%$ & Kurang baik \\
\hline 4. & $\leq 10$ & 0 & $0 \%$ & Tidakbaik \\
\hline
\end{tabular}

Sumber : Data primer yang sudah diolah

Dari Tabel di atas dapat diketahui bahwa tanggapan responden terhadap profesionalisme guru di siswa kelas X Madrasah Aliyah Muhammadiyah 02 Pondok Modern Paciran Lamongan terbesar pada interval 21 - 30 dan 11 - 20 keduanya sama-sama besar yaitu sebanyak 3 respoden atau $60 \%$. Dengan demkian dapat disimpulkan bahwa profesionalisme guru siswa kelas X di Madrasah Aliyah Muhammadiyah 02 Pondok Modern Paciran Lamongan dalam kategori "Cukupbaik".

\section{Data tentang Prestasi Belajar Siswa}

Peningkatan prestasi belajar siswa adalah adalah suatu hasil usaha dari hasil berlatih untuk mendapatkan pengetahuan oleh pelajar pada akademik atau perguruan tinggi.

Adapun indikator prestasi belajar siswa adalah:

a. Peningkatan pada aspek kognitif

b. Peningkatan pada aspek kognitif afektif

c. Peningkatan pada aspek kognitif psikomotorik

Data yang disajikan adalah data yang diperoleh melalui angket yang disebarkan 30 responden siswa kelas X. Angket ini terdiri dari 10 item, setiap soal disediakan 4 alternatif jawaban dengan ketentuan, jawaban A bernilai 4, jawaban B bernilai 3, jawaban C bernilai 2, 
dan jawaban D bernilai 1. Untuk lebih jelasnya penulis menyajikan jawaban siswa sebagaimana tabulasi data penelitian terlampir.

Berdasarkantanggapanrespondenterhadapprestasi belajar siswa pada lampiran tabulasi data hasil penelitian, maka dapat diklasifikasikan sebagaimana Tabel di bawah ini:

Tabel: Tanggapan Responden Terhadap Prestasi Belajar Siswa

\begin{tabular}{|c|c|c|c|c|}
\hline No & Interval Nilai & Frekuensi & Persentase & Keterangan \\
\hline 1. & $31-40$ & 3 & $10 \%$ & Baik \\
\hline 2. & $21-30$ & 16 & $53,3 \%$ & Cukupbaik \\
\hline 3. & $11-20$ & 11 & $36,6 \%$ & Kurang baik \\
\hline 4. & $0-10$ & 0 & $0 \%$ & Tidakbaik \\
\hline
\end{tabular}

\section{Sumber : Data primer yang sudah diolah}

Dari Tabel di atas dapat diketahui bahwa tanggapan responden terhadap peningkatan prestasi belajar siswa kelas X Madrasah Aliyah Muhammadiyah 02 Pondok Modern Paciran Lamongan terbesar pada interval 21 - 30 yaitu sebanyak 16 respoden atau 53,3\%. Dengan demikian dapat disimpulkan bahwa prestasi belajar siswa kelas X Madrasah Aliyah Muhammadiyah 02 Pondok Modern Paciran Lamongan dalam kategori "Cukup baik”.

Kemudian untuk mengidentifikasi pengaruh profesionalisme Guru terhadap peningkatan prestasi belajar siswa kelas X Madrasah Aliyah Muhammadiyah 02 Pondok Modern Paciran Lamongan, penulis menggunakan analisis data kuantitatif dengan mengubah data kualitatif kedalam bentuk angka.

Adapun rumus yang digunakan rumus korelasi pearson product moment. Selanjutnya penghitungan dilakukan dengan bantuan program SPSS12 for windows, dan hasilnya terlihat pada tabel 8 sebagai berikut.

Tabel: Korelasi Pearson Product Moment

\begin{tabular}{|c|l|r|r|}
\hline & & $\begin{array}{c}\text { Profesionalisme } \\
\text { Guru }\end{array}$ & PrestasiBelajarSiswa \\
\hline Profesionalisme & Pearson Correlation & 1 &, $610^{* *}$ \\
Guru & Sig. (2-tailed) & 5 &, 274 \\
& $\mathrm{~N}$ & & 5 \\
\hline PrestasiBelajarSiswa & Pearson Correlation &, $610^{* * *}$ & 1 \\
& Sig. (2-tailed) &, 274 & 30 \\
& $\mathrm{~N}$ & 5 &. \\
\end{tabular}

Sumber : Data Pearson Correlation 


\section{Analisis Data dan pengujian Hipotesis}

Untuk mengetahui pengaruh variabel bebas dan variabel terikat atau pengaruh profesionalisme Guru terhadap peningkatan prestasi belajar siswa kelas X, maka akan dianalisis dengan analisis korelasi Product Moment Program SPSS 12.00 for Windows maka diperoleh hasil 0,610 .

Sedangkan untuk menguji keyakinan (significant) dari hasil korelasi product momentatau $\mathrm{r}_{\text {hitung }}$ di atas akan dibandingkan dengan harga kritik $\mathrm{r}_{\text {table }}$ pada $\mathrm{N}=35$ taraf signifikan $5 \%$ atau 0,05 dalam hal ini harga kritik $\mathrm{r}_{\text {table }}$ product moment adalah 0,334 karena $\mathrm{r}_{\text {hitung }}$ berada di atas atau lebih besar dari harga kritiknya adalah 0,610 > 0,334 maka sedangkan, harga $r_{\text {hitung }}$ akan dikonsultasikan dengan Tabel interprestasi koefisien korelasi sebagaimana Tabel berikut ini:

Tabel: Interprestasi Koefisien Korelasi

\begin{tabular}{|c|c|}
\hline $\begin{array}{c}\text { Besar Nilai r } \\
\text { (Interval Koefision) }\end{array}$ & Interprestasi \\
\hline $0,800-1,000$ & Tinggi \\
$0,600-0,800$ & Cukup \\
$0,400-0,600$ & Agak rendah \\
$0,200-0,400$ & Rendah \\
$0,000-0,200$ & Sangat rendah \\
\hline
\end{tabular}

\section{Sumber : Suharsimi Arikunto, 2002. Prosedur Penelitian Suatu Pendekatan Praktik, Edisi Revisi V, Jakarta: Rineka Cipta, hal. 245.}

Jadi setelah dikonsultasikan pada Tabel interprestasi koefisien korelasi, nilai $r$ hitung berkisar antara 0,600 - 0,800 berarti korelasi antara profesionalisme Guru terhadap peningkatan prestasi belajar siswa kelas X Madrasah Aliyah Muhammadiyah 02 Pondok Modern Paciran Lamongan, menunjukkan dalam korelasi "positif yang cukup".

Kesimpulannya adalah karena $r_{\text {hitung }}>r_{\text {tabel, }}$ maka hipotesis yang penulis ajukan berupa Hipotesis Alternatif (Ha) yang berbunyi ada pengaruh profesionalisme Guru terhadap peningkatan prestasi belajar siswa kelas X Madrasah Aliyah Muhammadiyah 02 Pondok Modern Paciran Lamongan "diterima“. Sedangkan Hipotesis Nihil (Ho) yang berbunyi tidak ada 


\section{Pengaruh Profesionalisme Guru Terhadap}

Peningkatan Prestasi Belajar Siswa

pengaruh profesionalisme Guru terhadap peningkatan prestasi belajar siswa kelas X Madrasah Aliyah Muhammadiyah 02 Pondok Modern Paciran Lamongan. “ditolak”.

Jadi kesimpulannya terdapat hubungan positif yang signifikan antara profesionalisme Guru terhadap peningkatan prestasi belajar siswa kelas X Madrasah Aliyah Muhammadiyah 02 Pondok Modern Paciran Lamongan.

Untuk mencari besarnya sumbangan (koefisienditerminasi) variabel $\mathrm{X}$ terhadap variabel Y adalah:

$$
\begin{aligned}
\mathrm{KD} & =\mathrm{r}^{2} \cdot 100 \% \\
& =0,610^{2} .100 \% \\
& =0,3721.100 \% \\
& =37,21 \%
\end{aligned}
$$

Ini berarti bahwa profesionalisme Guru cukup mampu memberikan sumbangan atau kontribusi terhadap peningkatan prestasi belajar siswa kelas X Madrasah Aliyah Muhammadiyah 02 Pondok Modern Paciran Lamongan sebesar37,21\%. Selebihnya 62,79 \% dipengaruhi oleh factor lain. Misalnya situasi dan kondisi lingkungan keluarga dan sekitar, kepribadian dan minat belajar siswa, adanya sarana dan prasarana sekolah yang kurang mendukung.

\section{Kesimpulan}

Berdasarkan hasil penelitian di atas dapat disimpulkan sebagai berikut:

1. Profesionalisme Guru di Madrasah Aliyah Muhammadiyah 02 Pondok Modern Paciran Lamongan adalah "cukup baik". Kesimpulan ini dibuktikan dengan tanggapan responden terhadap Profesionalisme Guru (variable X) di Madrasah Aliyah Muhammadiyah 02 Pondok Modern Paciran Lamongan terbesar pada interval nilai 21 - 30 yaitu sebanyak 3 responden $(60 \%)$.

2. Adapun Peningkatan Prestasi Belajar Siswa Kelas X Madrasah Aliyah Muhammadiyah 02 Pondok Modern Paciran Lamongan dalam kategori "cukup baik" hal ini dibuktikan bahwa Prestasi Belajar Siswa Kelas X pada interval 21 - 30 yaitu sebanyak 16 responden (53,3 $\%)$.

3. Terdapat pengaruh positif yang cukup, Profesionalisme Guru Terhadap Peningkatan Prestasi Belajar Siswa Kelas X Madrasah Aliyah Muhammadiyah 02 Pondok Modern Paciran Lamongan. Hal tersebut dibuktikan dengan $r_{\text {hitung }}(0,610)>r_{\text {tabel }}(0,334)$ pada taraf 
signifikan $\alpha=0,05$. Dengan demikian Hipotesis alternatif (Ha) yang diajukan peneliti dapat "diterima" dan Hipotesis nihil (Ho) "ditolak".

4. Besarnya kontribusi Profesionalisme Guru Terhadap Peningkatan Prestasi Belajar Siswa Kelas X Madrasah Aliyah Muhammadiyah 02 Pondok Modern Paciran Lamongan adalah $37,21 \%$. 


\section{Daftar Rujukan}

Ahmadi, Abu dan Nur Uhbaiti. 1991. PsikologiBelajar. Jakarta: Rajawali

Arifin, Zainal, 1990. EvaluasiInstruksional. Bandung: Rosdakarya

Arikunto, Suharsimi. 2006. Prosedur Penelitian Suatu Pendekatan Praktik. Edisi Revisi VI, , Jakarta: Rineka Cipta

Aqib, Zainal, 2002. Profesionalisme Guru dalam Pembelajaran. Surabaya: Insan Cendekia

B. Suryosubroto,. 1997. Proses BelajarMengajar Di sekolah. Jakarta: PT. Rineka Cipta

Danim, Sudarwan. 2008. Visi Baru Manajemen Sekolah. Jakarta: PT. BumiAksara

Darajat, Djakiah. 2000. Ilmu Pendidikan Islam. Jakarta: BumiAksara

Departemen Agama Republik Indonesia, 1999. Al-Qur'an dan Terjemahannya. Semarang: Toha Putra

Departemen Pendidikan Nasional, 2001. KamusBesar Bahasa Indonesia. Jakarta: Balai Pustaka

Departemen Pendidikan Nasional, 2001. PeningkatanMutu Pendidikan di Sekolah Dasar. Jakarta: PEQIP

Djalinus Syah,, KamusPelajar Kata Serapan Bahasa Indonesia. Jakarta: Rineka Cipta

E. Mulyasa, 2008. StandarKompetensi dan Sertifikasi Guru. Bandung: PT. RemajaRosda Karya

Ibrahim, R. Nana Syaodih S. 1996. Perencanaan Pengajaran. Jakarta: Rineka Cipta

Muhaimin, Abdul Ghafir, Nur Ali Rahman. 1996. Strategi BelajarMengajar. Surabaya: Citra Media

Nasution, 1982. Asas-AsasKurikulum, Bandung: Jemmars

Santoso, Subhan Adi, 2017. Korelasi Motivasi Belajar Terhadap Prestasi Belajar Siswa Kelas X Mata Pelajaran PAI Di SMKN 13 Malang. Jurnal Tamaddun: Vol. 18 No. 1. 2017

Santoso, Subhan Adi, 2017. Pengaruh Kompetensi Pedagogik Guru Terhadap Prestasi Belajar Siswa Kelas XI Mata Pelajaran PAI Di SMKN 13 Malang. Jurnal Tamaddun: Vol. 18 No. 2. 2017

Santoso, Subhan Adi, 2020. Pengaruh Hafalan Ayat Al-Qur'an Terhadap Prestasi Belajar Siswa Mata Pelajaran Al-Qur'an Hadits Di Madrasah Ibtidaiyah Al-Azhar Serabi Barat Bangkalan. Jurnal Annaba: Vol. 6 No. 2. 2020

Santoso, Subhan Adi, 2020. Media Pembelajaran Pendidikan Agama Islam Era Industri 4.0. Yogyakarta: Deepublish 
Santoso, Subhan Adi, M. Chotibuddin, 2020. Pembelajaran Blended Learning Masa Pandemi. Pasuruan: Qiara Media

Sumardi Suryabrata, Proses BelajarMengaja di Perguruan Tinggi. Yogyakarta: Andi Offset Surkhmad, Winarno. 1980. MetodologiPengajaran Nasional. Bandung: Jammers

Suryabrata, Sumardi, Proses BelajarMengaja di Perguruan Tinggi. Yogyakarta: Andi Offset

Yusuf, Tayar, Syaiful Anwar, 1995. MetodologiPengajaran Agama dan Bahasa Arab. Jakarta: Raja Grafindo 